\title{
Can cigarette smoking worsen the clinical course of cluster headache?
}

\author{
I Tiraferri", F Righi, M Zappaterra, M Ciccarese, LA Pini, A Ferrari, MM Cainazzo \\ From The European Headache and Migraine Trust International Congress \\ London, UK. 20-23 September 2012
}

\section{Introduction}

Up to $90 \%$ of cluster headache $(\mathrm{CH})$ patients have a prolonged history of cigarette smoking prior to the headache onset. It has been suggested a genetic link between $\mathrm{CH}$ and nicotine addiction and, also, that toxic agents found in cigarette smoke have a direct effect on the hypothalamus, a pivotal area for the pathogenesis of $\mathrm{CH}$. [1-3]

\section{Purpose}

To explore the relationship between cigarette smoking and the clinical course of cluster headache.

\section{Methods}

All outpatients with cluster headache, diagnosed according to the criteria of ICHD-II, who were, consecutively, seen from October 2010 to April 2012 at the Headache Centre, were subjected to a phone interview by means a specific standardized questionnaire (29 items), administered, always, by the same trained post-graduate medical doctor.

\section{Results}

A total of 200 patients were surveyed (172 male, 28 female; mean age \pm SD: $48.4 \pm 12.7$; male/female ratio: $6.1: 1)$. One hundred and twenty patients were current smokers, 42 former smokers and 38 non-smokers. The age of onset of $\mathrm{CH}$ was $29.8 \pm 13.6$ years. Among all smokers and former smokers those who started smoking before age of 18 years had an onset of cluster headache earlier than those who started smoking after age of 18 years $(\mathrm{P}<.01$, Student's $t$ test). All patients with chronic cluster headache were currently smokers. The episodic form $(89 \%)$ was more frequent than the chronic one (11\%). Chronic $\mathrm{CH}$ patients smoked more cigarettes per day $(\mathrm{P}<.01$, Student's $t$ test $)$ and started smoking before $(\mathrm{P}<.01$, Student's $\mathrm{t}$ test $)$ than patients with episodic CH ( $\mathrm{P}=.001$, Student's t test). The length of the

Headache and Drug Abuse Interdepartmental Research Centre and Antismoking Centre University of Modena and Reggio Emilia, Italy active phase of $\mathrm{CH}$ was tripled compared to non-smokers (weeks \pm SD: $15.1 \pm 17.6$ vs. $5.7 \pm 4.7 ; \mathrm{P}<.001$, Student's t test).

\section{Conclusion}

Our data showed that cigarette smoking is an aggravating factor for cluster headache, in particular for the lasting of the active phase.

\section{Competing interests}

None.

Published: 21 February 2013

References

1. Schürkus M, Diener HC: Cluster headache and lifestyle habits. Curr Pain and Headache Rep 2008, 12:115-121.

2. Rozen TD: Cluster headache as the result of second hand cigarette smoke exposure during childhood. Headache 2010, 50:130-132.

3. Rozen TD: A history of cigarette smoking is associated with the development of cranial autonomic symptoms with migraine headache. Headache 2011, 51:85-91.

doi:10.1186/1129-2377-14-S1-P54

Cite this article as: Tiraferri et al:: Can cigarette smoking worsen the clinical course of cluster headache? The Journal of Headache and Pain 2013 14(Suppl 1):P54.

Submit your manuscript to a SpringerOpen ${ }^{\odot}$ journal and benefit from:

- Convenient online submission

- Rigorous peer review

- Immediate publication on acceptance

- Open access: articles freely available online

- High visibility within the field

- Retaining the copyright to your article

Submit your next manuscript at $>$ springeropen.com (c) 2013 Tiraferri et al; licensee Springer. This is an Open Access article distributed under the terms of the Creative Commons Attribution License (http://creativecommons.org/licenses/by/2.0), which permits unrestricted use, distribution, and reproduction in any medium, provided the original work is properly cited. 